UDC 347.44:004.891

DOI:10.5937/RKSPP1901073D

MATEJA DUROVIC

FRANCISZEK LECH

\title{
THE ENFORCEABILITY OF SMART CONTRACTS
}

The development of new technologies has different effects on the existing law. Smart contracts are one of the forms of the new technologies that questions the application of the traditional contract law on commercial transactions using smart contracts. In that context, the enforceability of contractual transactions concluded in the form of smart contracts represent one of the major legal questions. Moreover, the question is whether the existing English contract law needs to be modified in order to secure the enforceability of smart contracts. These issues will be, accordingly examined in this paper with the aim to understand better the relationship of the traditional contract law, on the one side, and, smart contracts, on the other side.

Key words: smart contracts, contract law, disruption, new technologies, AI, enforceability

\section{INTRODUCTION}

In the recent years, businesses have started increasingly applying smart contracts for a number of diverse commercial transactions. In that context, the principal legal question is whether commercial transaction concluded through the smart contracts will be enforceable before the court. The main legal issue herein is

Dr. Mateja Durovic, LLM (Cantab.), Reader in Contract and Commercial Law, The Dickson Poon School of Law, King’s College London, e-mail: mateja.durovic@kci.ac.uk

Franciszek Lech, Research Associate in Law, King’s College London, e-mail: franciszek@kci.ac.uk 
to understand the relationship between the smart contracts, on the one side, and traditional contract law, on the other side.

Therefore, the main objective of this paper is to contribute to the explanation of that relationship in order to understand whether smart contracts are, from the perspective of the traditional contract law, enforceable. This topic has recently attracted a lot of attention in the United Kingdom and this paper will focus on the enforceability of smart contracts under the English law. In that sense, it will be useful to see how common law, as traditionally more business focused and commercial friendly system of rules, respond to the application of the new technologies in commercial transactions.

\section{THE EXPLANATION OF SMART CONTRACTS}

When discussing smart contracts, the first question to touch upon is the terminology and the meaning of the term. The question is whether smart contracts are really contracts at all where a smart contract is just a type of contract. In the existing scholarship, there is a tendency to draw dichotomies and lament vague and confused nomenclature or point out that the notion "smart contract" is actually a misnomer, that smart contracts are neither smart nor that they are contracts, which seems to be true. It has been remarked that "Smart Contract" is an ironic and unfortunate misnomer, and it would be better off being referred to as 'an "automated transaction manager" or "ATM", but that... has already been taken. ${ }^{1}$ Likewise, the mainstream thinking about smart contracts is substantially questioned, and (one may argue) rightly urges restraint in proclaiming Smart Contracts as the panacea to all inefficiencies of the legal system, rendering Law, or particularly Contract Law, obsolete. The same authors continue by pointing out how people confuse Blockchain technology with Smart Contracts and vice versa, forgetting that conceptually the two are independent of each other. ${ }^{2}$

Pardolesi and Davola argue that "[a]ll topics [of interpretation, arbitration, liability etc], nonetheless, deserve attention only if we believe that a smart contract is, at the very end, a (type of) contract: if, on the contrary, they represent mere tools susceptible to be encompassed within the (traditional) contractual practice - as part of legal scholarship defends -, then all these questions are devo-

1 Jeffrey M. Lipshaw, "Persistence of 'Dumb' Contracts”, Stanford Journal of Blockchain Law \& Policy, Vol. 2, 2019, p. 12, available at SSRN at: https://papers.ssrn.com/sol3/papers.cfm?abstract_ $\mathrm{id}=3202484,25.09 .2019$.

2 Roberto Pardolesi, Antonio Davola, "What is Wrong in the Debate About Smart Contracts", Luiss Guido Carli University Working Paper, 2019, available at: https://papers.ssrn.com/sol3/ papers.cfm?abstract_id=3339421, 25.09.2019. 
id of their primary foundations" ${ }^{3}$ This is especially relevant in context of the above question, casting doubt on the understanding of the concept. If we are to believe that writing contract terms in code is a mere method of streamlining the performance of contracts, then the code itself will not have to be enforceable (as it will always be pegged to some other, at least implied, contract). It is submitted that, all in all, Smart Contracts, potentially will be a type of contract, rather than just an automation of contractual performance.

What seems to be the case is that legal contracts will require, at least for the near future, a blend between code and natural language. ${ }^{4}$ These ties in with the previous point about Smart Contracts being a method of performance of parts or entire commercial transactions, rather than a contract. Together they lead to an ad hoc answer to the question: smart legal contract can be enforceable when it is a part of an otherwise enforceable and valid natural language contract, imposing a method of performance. That much seems obvious. If two parties agree on a method of performance the court is extremely unlikely to invalidate such a clause because it pertains to an automated coded method.

Some commentators go as far as to claim that 'smart contracts' are merely computer programmes that parties use to perform their contracts not agreements or contracts. ${ }^{5}$ Allen's view is a riposte to the critique laid out by Pardolesi et al. arguing that: 'there is no barrier to a single instrument, written in formal language [i.e code], embodying both the contract as such and its automated mechanism of performance's.

Not only then is there wide divergence in views, but in terminology itself. United Kingdom JT defined "smart legal contracts" as 'a smart contract capable of giving rise to binding legal obligations, enforceable in accordance with its terms'; It seems more likely to understand smart contracts as a combination of the 'smart contract code' and traditional legal language in juxtaposition to a smart contract which is 'computer code.'

3 Ibidem, p. 6.

4 Mateja Durovic, Andre Janssen, "The Formation of Smart Contracts and Beyond: Shaking the Fundamentals of Contract Law?", 2018, p. 24, available at https://www.researchgate.net/publication/327732779_The_Formation_of_Smart_Contracts_and_Beyond_Shaking_the_Fundamentals_ of_Contract_Law, 25.09.2019.

5 Pierluigi Cuccuru, "Beyond Bitcoin: An Early Overview On Smart Contracts", International Journal of Law and Information Technology, Vol. 25, No. 3, 2017, pp. 179, 185.

6 J.G. Allen, "Wrapped and Stacked: "Smart Contracts" and the Interaction of Natural and Formal Language" (2018) 14(4) ERCL 307, available on SSRN: <https://papers.ssrn.com/sol3/papers.cfm?abstract_id=3297425>, (n ), pp. 2-3.

7 M. Durovic,A. Janssen, p. 5. 
Cenkus Law instead posited that a 'smart legal contract' is: 'a particular application of that type of code [a smart contract]...used to form an organization... used to run an application or it can be used... to actually facilitate a binding legal agreement.' ${ }^{8}$ Differently still, Madir argued that they are 'functionally made up of pieces of smart contract code, but critically under the umbrella of an overall relationship that creates legally enforceable rights. ${ }^{9}$ Hence, while everyone postulates for clarity in definitions that is far from true, complicating vastly the actual task of consensus.

As to 'pure' smart contracts - contracts fully in code the position is more difficult. 'smart [legal] contracts can, in principle, fulfill the requirements for the formation of contracts, and the problems are not unbridgeable. ${ }^{10}$ It should be pointed out that smart contracts are capable, by virtue of the flexibility and adaptability of the English contract law, and the very process of their formation, be capable of being formed as legally valid contracts, and thus truly "contracts".

There is a strong discrepancy when it comes to the views of the legal scholars on enforceability range from 'business as usual to predicting the end of contract law. ${ }^{11}$ In principle, it is still unlikely that an otherwise valid and enforceable contract would be deemed ineffective merely because expressed in code. This would be also contrary to the fundamental principle of freedom of contract under English law which entitles also freedom to choose any kind of form for contractual relationships.

There are perhaps a couple of nuances and caveats that should be made. Allen usefully remarked that: ${ }^{12}$

We do not need imagine two stateless castaways swapping fish for coconuts on the high seas to accept the basic proposition that while economic activity nestles within the substrate of a legal system, where one exists, it can also thrive outside the law. Trying to understand smart contracts, and how they might change the contract law of the future, is therefore not an exercise best undertaken from a perspective that puts national law indicia in the foreground. Given the fundamental challenges that Internet-based commerce

8 Cenkus Law, 'Smart Legal Contracts: Explanation and Enforceability', available at: https:// cenkuslaw.com/smart-contracts-explained-legally-binding/, 25.03.2018.

9 Jelena Madir, "Smart Contracts: (How) Do They Fit Under Existing Legal Framework", p. 3, available on SSRN at: https://poseidon01.ssrn.com/delivery.php?ID=44 ... 104\&EXT=pdf, 25.09.2019.

10 M. Durovic, A. Janssen, p. 17.

11 J.G. Allen, "Wrapped and Stacked: "Smart Contracts" and the Interaction of Natural and Formal Language' (2018) 14(4) ERCL 307, available on SSRN: <https://papers.ssrn.com/sol3/papers.cfm?abstract_id $=3297425>, 1-2$

12 Ibidem, p. 11. 
poses for the system of territorial-based jurisdiction as a whole, it seems disingenuous to deny at the outset that a trans-national body of norms might arise to regulate trans-national ecommerce and e-finance.

Therefore, a criticism has been made of the approach that faces off the fundamental elements of a contract in a given jurisdiction ("indicia") with the elements of a smart legal contract. It should however be noted that in answering the question in what circumstances a smart legal contract is capable of giving rise to enforceable legal obligations one has to consider the "indicia" of English contract law. Hence, the conclusion reached about the individual elements of a valid contract remains pertinent and is a strong argument in favour of perceiving smart legal contracts as valid contracts in Contract law's eyes. ${ }^{13}$

Perhaps we need to remind ourselves that 'the use of binary codes to incorporate and computerize parts of a contract is not a brand-new phenomenon: for example, the usage of electronic format to digitally communicate was already diffused in the product chain before internet and e-commerce got massively exploited through EDI (electronic data interchange) technologies,', ${ }^{4}$ and that 'A blockchain or distributed ledger is similar to any other IT-based message platform used to agree on transactions. Courts have already accepted that the exchange of the email messages can give rise to legally binding contracts in many jurisdictions. Automated performance is common in equities markets and algorithm trading. Existing contract laws (including e-commerce laws), therefore, may in many instances suffice in the case of the formation of smart legal contracts. ${ }^{15}$

The broad consensus seems to be that 'pure' Smart Contract (a piece of computer code that encompasses all elements of the parties agreements and is self-standing and independent of any natural language document) can be a legally enforceable contract - if both parties have transparency and clarity (had understood, had time to consider and decided to enter into such an arrangement) as to what the code entails, the computer logic encoded in the Smart Contract, then they can be bound by the outcomes (including, in theory, other subsequent arrangements entered into by the Smart Contract autonomously), provided that the elements of the contract such as offer, acceptance, consideration and in-

13 M. Durovic, A. Janssen, p. 24.

14 R. Pardolesi, A. Davola, p. 17

15 US Chamber of Digital Commerce, “Smart Contracts: Is the Law Ready?”, p. 35, available at: https://digitalchamber.org/smart-contracts-whitepaper/, 25.09.2019 (hereinafter: US Chamber of Digital Commerce). 
tention to create legal relations are present. ${ }^{16}$ Thus we again return to the issue of offer, acceptance, consideration, intention to create legal relations and capacity. That these elements are capable of being satisfied using in a normal smart legal contract formation procedure seems to be undisputable.

Another point is that contract law has to remain flexible to the changing commercial circumstances without the need for major revisions of principle: it had done so throughout times adapting to other forms of remote communication such as telex ${ }^{17}$ or email ${ }^{18}$. Automated performance is commonplace in algorithm trading and equities markets. ${ }^{19} \mathrm{~T}$ here's little reason to think that smart contracts will be different. ${ }^{20}$ Under the English law, parties are free to agree their desired form of communication of acceptance ${ }^{21}$, and so a cryptographic signature should be sufficient.

Furthermore, parties can even specify what kind of smart contract communication will constitute acceptance ${ }^{22}-$ is it entering the external cryptographic key (more suitable for longer term contracts, where performance is some time in the future) or simply performance of the bargain - say uploading 10 Ether to the smart contract. Once the parties have validly and voluntarily entered into the initial contract, the Smart Contract can then enter the parties into additional contracts, which would bind the parties. ${ }^{23}$ Any avoidance of doubt could be achieved by a requirement that prior to concluding a smart contract a user is asked to accept the natural language translation of the contract terms and communicate his consent (by clicking 'I agree'). ${ }^{24}$

Such a conclusion is not accepted by some commentators. Gonzales et al. argued that Smart Contracts 'are not contracts in the legal sense' because the 'do

16 Ashurst LLP, "Smart Contracts - Can Code Ever Be Law?", available at: https://www. ashurst.com/en/news-and-insights/legal-updates/smart-contracts---can-code-ever-be-law/, 25.09.2019 (hereinafter: Ashurst LLP).

17 Entores Ltd v Miles Far East Corpn [1955] 2 QB 327, 333 (Denning LJ).

18 For example: Nicholas Prestige Homes v Neal [2010] EWCA Civ 1552, [9]-[12], [20] (Ward LJ).

19 US Chamber of Digital Commerce, p. 35.

20 Colin Adams at Research Institute, 'Smart Contracts, Part 2: The Legality', Hackernoon, 2018.

${ }^{21}$ Holwell Securities $v$ Hughes [1974] 1 All ER 161, 163 (Russell LJ).

22 J. Madir, p. 8

${ }^{23}$ Ibidem, p. 8.

24 Clifford Chance, "Smart Contracts: Legal Agreements for the Digital Age" (No 2017), available at: <https://talkingtech.cliffordchance.com/content/micro-cctech/en/emerging-technologies/smartcontracts/smart-contracts/_jcr_content/text/parsysthumb/download/file.res/Smart\%20contracts.pdf>, 25.09.2019. 
not necessarily facilitate or embody exchanges, which all contracts do by definition', instead arguing that Smart Contracts are 'a programming tool, that is too limited to be able to disrupt legal contract practice or deliver on its promise of selfenforcing performance, because enforcement results from a dispute through the mechanisms of the legal system.'. 25 This argument, with respect, is unacceptable and can be refuted. First, it is not part of the 'legal' definition of a contract that it must 'facilitate or embody exchanges', neither is it fully true that Smart Contracts do not do that. Smart Contracts (in the narrow sense meaning computer code) are a tool that enables assets (or their digitized tokens) to change hands if a condition was satisfied - and as such they do 'facilitate' an 'exchange' of those assets. Furthermore, 'enforcement' of an agreement does not (a) result from a dispute; (b) does not have to be necessarily implemented by the State via the judicial system. Parties can self-enforce etc.

Smart Contracts can be said to be self-enforcing in the sense that once the Smart Contract has been concluded, and is stored on a blockchain, if the condition is satisfied the assets will change hands, even if the original parties to the contract no longer wish them too. They can also be said to be self-enforcing in the sense that the discretion whether or not to abide by the terms of the contract is taken away from the parties, and once they have concluded a Smart Contract they will abide by the terms (generally). Accordingly, it is submitted that this kind of broad attacks on Smart Contracts' identity as contracts can be rejected, and it cannot be stated that Smart Contracts will never be contracts.

Another line of argument is that 'smart contracts are... not agreements they are technology for enforcing agreements. ${ }^{26}$ The argument goes that a piece of code unaccompanied by any legal terms 'may not satisfy the requirement of a legally binding contract.'27 This objection could be met in two ways: (1) it is clear that if a smart contract is just a method of performing of one or more clauses of a natural language (traditional) contract, then the code itself will not be the contract; (2) a pure smart contract (without a corresponding natural language contract) will not be a valid binding contract unless the elements discussed above are satisfied. Accordingly, it is wrong to state that a smart contract will "never" be a legally-valid contract, it is right to think that some Smart Contracts will fall short of constituting a valid contract, just as a note or natural language communication

25 Alvaro Gonzales Rivas, Mariya Tsyganova, Eliza Mik, 'Smart Contracts and Their Identity Crisis', p. 8, available at:https://papers.ssrn.com/sol3/papers.cfm?abstract_id=3319612, 25.09.2019.

26 See C. Adams.

27 See A shurst LLP. 
may fall short of constituting a traditional contract because some defining requirement of a contract in law is missing. ${ }^{28}$

Lastly, a comparative, common law observation can be made. In the United States, a number of states have passed "blockchain legislation" which expressly have recognised Smart Contracts as capable of giving rise to enforceable legal obligations. In Arizona, the State Legislature has passed a law that states that 'Smart Contracts may exist in commerce. A contract relating may not be denied legal effect, validity or enforceability solely because that contract contains a smart contract term'. ${ }^{29}$ Likewise Tennessee passed a law that states that ${ }^{30}$ :

\$ 47-10-201: (...) "Smart contract" means an event-driven computer program, that executes on an electronic, distributed, decentralized, shared, and replicated ledger that is used to automate transactions, including, but not limited to, transactions that: (A) Take custody over and instruct transfer of assets on that ledger; (B) Create and distribute electronic assets; (C) Synchronize information; or (D) Manage identity and user access to software applications.

$\$$ 47-10-202: (a) A cryptographic signature that is generated and stored through distributed ledger technology is considered to be in an electronic form and to be an electronic signature. (b) A record or contract that is secured through distributed ledger technology is considered to be in an electronic form and to be an electronic record. (c) Smart contracts may exist in commerce. No contract relating to a transaction shall be denied legal effect, validity, or enforceability solely because that contract is executed through a smart contract.

These Acts ensure that smart contracts can be recognized as legally valid, and moreover, that they can fulfill both the "in writing" and the signature requirements, essentially extending the E-Commerce and Electronic Transactions Provisions to cover Smart Contracts. Apart from these acts, several states such as Florida $^{31}$, Maryland and Nebraska introduced State Legislation dealing with DLTs and Smart Contracts. A great overview is provided by the National Conference

${ }^{28}$ For example: May and Butcher Ltd $v$ The King [1934] 2 KB 17, 21 (Viscount Dunedin) incomplete agreement or Felthouse v Bindley (1862) 142 ER 1037, 1040 (Keating J) - no acceptance.

29 Arizona Revised Statutes, Title 44 Trade and Commerce, $\$ 44-7601 \mathrm{C}$, available at: https:// www.azleg.gov/ars/44/07061.htm, 25.09.2019.

30 Tennessee Code, Title 47 (Commercial Instruments and Transactions), Chapter 10, $\$ 201$ as amended by Senate Bill 1662, available at: https://legiscan.com/TN/text/SB1662/2017, 25.09.2019.

31 Florida House Bill 1357, $\$ 7(1)(b),(2)$, available at: http://www.flsenate.gov/Session/ Bill/2018/1357/BillText/Filed/PDF, 25.09.2019. 
of State Legislatures website. ${ }^{32}$ In relation to that zone, and as part of an experiment, the residents were granted a right to 'to carry out performance and/or execution of transactions by means of a smart contract' and, interestingly the law introduces a presumption that whoever enters into a Smart Contract understands its terms. ${ }^{33}$ Thus if English courts were to strike down pure Smart Contracts as unenforceable, England would be lagging behind other jurisdictions - perhaps yet another reason why a court in England and Wales would be unlikely to declare that a Smart Contract can never be a Legal Contract.

The foregoing considerations point to a conclusion that a smart legal contract is capable of giving rise to enforceable legal obligations when it satisfies the traditional elements required for contract formation. As stated correctly by Lord Hodge JSC, 'so long as the operation of the computer program can be explained to judges who, like me, may be deficient in our knowledge of computer science, it should be relatively straightforward to conclude that people who agree to use a program with smart contracts in their transactions have objectively agreed to the consequences of the operation of the "if-then" logic of the program.34

From a comparative law perspective, it is useful to have a look at what some of the civil law jurisdictions have done in respect of recognition of enforceability of smart contracts. In that sense, Italy seems to be the most prominent example because it is among the first European jurisdictions which, in 2019, has introduced specific smart contract legislation recognizes smart contract's full legal validity and enforceability in Italy. ${ }^{35}$ This law has introduced a definition of Smart Contracts and has set out the legal effects of adopting such technologies. Accordingly, smart contracts are defined as "computer programs that operate on distributed registers-based technologies and whose execution automatically binds two or more parties according to the effects predefined by said parties" ${ }^{36}$ Importantly, the same law points out that the smart contracts will satisfy the requirement of

32 NCSL, 'Blockchain State Legislation', available at: http://www.ncsl.org/research/financialservices-and-commerce/the-fundamentals-of-risk-management-and-insurance-viewed-throughthe-lens-of-emerging-technology-webinar.aspx, 25.09.2019.

33 Decree of the President of the Republic of Belarus of December 21, 2017 No 8. On Development of Digital Economy, Art. 5.3. English Translation available at: http://law.by/document / guid=3871\&p0=Pd1700008e, 25.09.2019.

34 Lord Hodge, "The Potential and Perils of Financial Technology: Can the Law Adapt to Cope?", p. 11, available at: www.supremecourt.uk/docs/speech-190314.pdf, 25.09.2019.

35 Law Decree No. 135/2018.

36 Article 8-ter(2) (Tecnologie basate su registri distribuiti e smart contract) Law Decree No. $135 / 2018$. 
the written form (forma scritta) of a contract if such a form is required under the Italian law and that is something that is discussed in this paper in the context of English law and written form requirements for a valid contract.

\section{THE ISSUE OF INTERPRETATION OF SMART CONTRACTS}

The interpretation of smart contracts is a particularly challenging task. ${ }^{37}$ The standard view is that 'legal contracts are written in natural language, which is full of ambiguity, and must be interpreted subjectively by fallible humans. Smart contracts are written in programming languages, which are unambiguous and executed objectively by infallible computers' which could suggest that interpretation will be obsolete - allegedly the time of ambiguity has come to an end. This view is too good to be true. ${ }^{38}$ However, it needs to be pointed out that even computer code can be ambiguous: yes the commands are written in straightforward $<$ if $><$ then $>$ logic, but what the code means is determined by its context and conventions in the communities - which are not as straightforward and change over time. His example includes looking at different versions of Python (coding language) and demonstrating that the meaning of a symbol such as " $\wedge$ " for example change - leading the same code to produce different outcomes.

Hence, it is submitted that coding language is not a panacea to linguisticalambiguousness, and canons of interpretation will remain utilized. Let us first focus on a situation where the agreement between two parties (collectively the "contract") is containedin both natural language memorandum, and a smart contract code. Allen's interesting thesis is that all contractual promises are not a statement but an "intentional speech act" - namely conduct signifying something else - in the contractual sense by making an offer I am evidencing an intention to be bound on the terms of my offer. By attributing this characteristic to a contractual promise his logical conclusion is that there is no requirement for any of the contractual communication to be in natural language, since what is actually being conveyed is secondary to the intention that the conveyance evidences. Allen reasons that there is thus no obstacle for a computer code to satisfy the "intentional speech act" requirement and lead to a valid legal obligation..$^{39} \mathrm{He}$ also argues that

37 Michel Cannarsa, "Interpretation of Contracts and Smart Contracts: Smart Interpretation or Interpretation of Smart Contracts?", European Review of Private Law, Vol. 26, No. 6, 2018, pp. 773-785.

38 James Grimmelmann, "All Smart Contracts Are Ambiguous", Penn Journal of Law and Innovation (Forthcoming), p. 2.

39 J.G. Allen, pp. 15-16. 
a contract can be conceptualized as a "stack" which is composed of certain layers within that stack:

A 'paper' contract, comprises (i) the spoken words through which the contractual terms were negotiated and against which the text was drafted, (ii) the written text, and (iii) legal rules implying terms and governing construction... In a smart contract, (ii) is complemented (or supplanted) by code which is also, incidentally, wholly or partially executable by a machine. ${ }^{40}$

Furthermore, a smart contract will be a result of some understanding between the parties which is expressed in natural language (since no humans think in computer code) and so the courts should be able to work their way backwards from the code to the objective intentions of the parties etc. This part of Allen's argument however falls when confronted with the fact that a smart contract may be capable of entering into other smart contracts with other parties and so there may be no natural language equivalent for some of the provisions. 'Some terms in the smart contract may be concerned with details that are left implicit in the natural language formulation.

On the other hand, there may be clauses in the natural language contract that are not included in the smart contract, since their automation is not necessary, possible or even desirable. ${ }^{31}$ Still it is likely that courts would approach the interpretation of the contract in relation to a broad equivalent of the coded term in natural language, the same way that the court deals with foreign languages by having them translated into English. ${ }^{42}$

If we take the principles of interpretation famously laid out famously by Lord Hoffmann in ICS, especially the first two principles:

(1) Interpretation is the ascertainment of the meaning which the document would convey to a reasonable person having all the background knowledge which would reasonably have been available to the parties in the situation in which they were at the time of the contract.

(2) The background was famously referred to by Lord Wilberforce as the 'matrix of fact', but this phrase is, if anything, an understated description of what the background may include. Subject to the requirement that it should have been reasonably available to the parties and to the exception to be mentioned next, it includes absolutely anything

40 Ibidem, pp. 18-19.

${ }^{41}$ Guido Governatori, Régis Riveret, Xiwei Xu Florian Idelberger, Giovanni Sartor, Zoran Milosevic, "On Legal Contracts, Imperative and Declarative Smart Contracts and Blockchain Systems", Artificial Intelligence Law, Vol. 26, 2018, pp. 377, 385.

42 For example: United Company Rusal v Crispian Investments Ltd [2018] EWHC 2415 (Comm), [15] (Phillips J). 
which would have affected the way in which the language of the document would have been understood by a reasonable man. ${ }^{43}$

Accordingly, the court would have an insight into the 'background' which would include the natural language understanding of the parties (or any natural language 'wrapper' contract) and would interpret the code against that background. The only problem becomes apparent when we compare Lord Hoffmann's approach with a more recent approach endorsed by the UK Supreme Court, which stresses that the factual matrix should not be invoked to undervalue the importance of the language of the provision which is to be construed, and allows recourse to the background only where there is ambiguity. ${ }^{44}$ While the difference may appear minute the significance for smart contracts is profound. As argued by Allen, a computer code, if functional (meaning capable of being run, or one that has run successfully) is by definition not ambiguous and clear ${ }^{45}$, which leads to the paradox that 'if ambiguity is prerequisite for context to play a role in interpretation and/or construction, the court will never get to the point of asking whether the algorithm's product is really what the human parties intended-even in perverse cases. ${ }^{46}$

Allen's solution is that courts will have to adapt the established canons of interpretation to look at the context more readily and develop dictionaries which would translate in meta-language the computer code to aid the court reasoning in natural language to distill meaning from computer code.

One can of course also let imagination run wild and suggest that in the notso-distant future we will have AI or automated dispute resolution procedures, which will be able to scan the computer code, verify it through an Oracle to confirm say absence of duress, illegality etc, and then deliver a verdict. That at this point, even with the new dispute-resolution technologies already in place or being implemented seems to be more like a fancy though. This is why the English courts should be able, without a radical re-organisation of their canons of interpretation to interpret computer code via a method of translation to natural language.

${ }^{43}$ Investors Compensation Scheme Ltd v West Bromwich Building Society [1998] 1 All ER 98, p. 115.

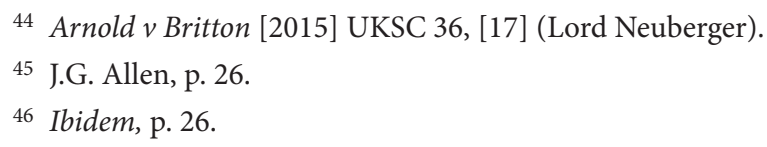




\section{THE ANONYMOUS OR PSEUDO-ANONYMOUS PARTIES AS CONTRACTUAL PARTIES}

Most blockchain software do not require 'any pre-identification of the users', with the parties appearing simply as 'long strings of random numbers and letters'. Each user is equipped with a pair of cryptographic key (a public and private one) generated by independent software wallets and kept there. ${ }^{47}$ This means that parties can enter into a smart contract without knowing anything about the counterparty except the long string of random numbers and letters that appears.

Technically there is no requirement of knowing the identity of a party with which one contracts. People are free to make an offer to the entire world which would ripen into a contract with whomever acted on it as pointed out in Carlill v Carbolic Smoke Ball Company more than hundred years ago. ${ }^{48}$ This suggests that contracts can be made with parties fully anonymous to the offeror - evidently the defendant had no idea that it was in a binding contract with Mrs. Carlill until she informed them that she wants the $£ 100$ reward. Thus, normally a smart contract is capable of giving rise to pseudo-anonymous parties, subject of course to the claimant's ability to prove that (a) they entered into the contract - proof that the cryptographic key is theirs and they used it and (b) identifying who to sue, which can both form significant practical obstacles to enforcement or (more likely given their nature) revision of a Smart Contract via the judicial path. Perhaps as smart legal contracts become more ubiquitous the 'host' of the blockchain (such as Ethereum for example) would provide a mechanism to identify the parties.

Anonymity is a particular obstacle in relation to contracts subject to a statutory "in-writing" requirement ${ }^{49}$ (discussed below). For example, under the US Statute of Frauds the 'essentials' of the contract must be in writing, and 'essentials' include names of the contracting parties. ${ }^{50}$ Furthermore, to be valid identification of a party 'the parties [must] be described in such a manner as that there can be no fair or reasonable dispute as to the person who is selling or buying. ${ }^{51}$ Even if the parties know each other identities, but they are not sufficiently identified in the contract, the contract will be invalid. ${ }^{52}$ While it is unlikely that an interest in land

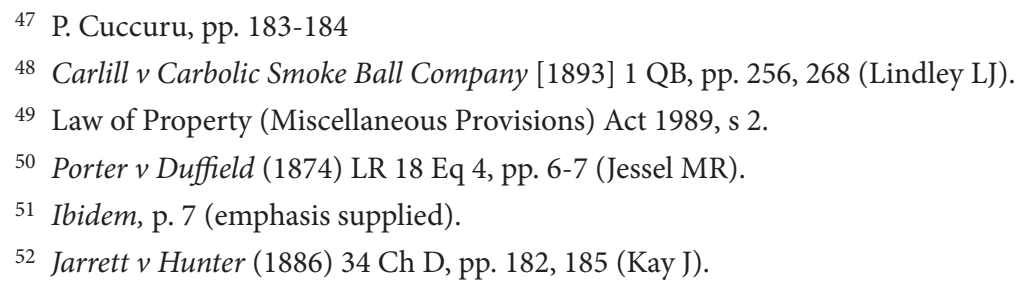


would be transferred in a smart contract transaction (given the subsequent registration requirements, and the early stages and doubts surrounding the technology), and thus s 2 LP(MP)A 1989 is unlikely to be key, it is possible that in a contract that is subject to "in writing" requirement, and thus where parties must be identified smart contracts will fall below the required standard. After all given a string of random letters and numbers there is a possibility of a 'reasonable dispute' as to the identity of the person who is selling or buying.

A solution could be to interpret "person" to mean a public address on the blockchain - which means that parties are sufficiently identified whenever it is clear that this cryptographic key (and the person, whomever it is, behind that key) entered into the contract, even if the actual, off-line identity of the ultimate user is unknown. Tse identified flaws with such an approach, namely that (1) a public address (key) may point to a different smart contract rather than a wallet of a user and (2) the owner of the wallet remains pseudonymous. His solution to advocate for 'development of blockchain identities', which was also discussed above. ${ }^{53}$ For most contracts, the pseudonymity will be a practical obstacle to judicial enforcement, rather than an ex ante obstacle to forming a binding legal relationship.

\section{FULFILMENT OF THE SIGNATURE REQUIREMENT BY USING A PRIVATE KEY}

The statutory requirement that will be discussed by way of example will be $\mathrm{s}$ 2 LP(MP)A 1989. The classic interpretation of the word "signed" in s 2(3) LP(MP) A 1989 imposes an ordinary, common sense, meaning on the word an act analogous to putting one's name on the document with their own hand. ${ }^{54}$ Thus typing a name on a letter as an addressee does not constitute a signature. ${ }^{55}$ The Court of Appeal also held that the signature must be 'obviously so as to authenticate ${ }^{56}$ the document', and that the policy of the requirement is motivated by the desire to prevent a party to 'go behind the document and introduce extrinsic evidence to establish a contract. ${ }^{57}$

53 Gary Tse, "Smart Contracts: A Boon or Bane For the Legal Profession", available at: https://www.taylorvinters.com/article/smart-contracts-a-boon-or-bane-for-the-legal-profession, 25.09.2019.

54 Goodman v J Eban Ltd [1954] 1 QB 550, p. 555 (Denning LJ).

55 Firstpost Homes Ltd v Johnson [1995] 4 All ER, pp. 355, 362 (Peter Gibson LJ).

56 Caton v Caton (1867) LR 2 HL 127, pp. 142-143 (Lord Westbury).

57 Ibidem, p. 365 (Balcombe LJ). 
This broader proposition is central to answer the question. A cryptographic key is inputted to a smart contract precisely to authenticate the contract, but also to demonstrate assent to the Smart Contract, and prevent a contract being concocted or imposed on a party without their consent. Thus, the private key operates to fulfill the substance behind the signature requirement, and the only possible obstacle would be the form. An automated email containing a name of the party was taken to constitute a valid signature, ${ }^{58}$ and it is submitted that an intentionally placed cryptographic key or password is only a fortiori.

Electronic signatures have been recognized as valid by statute ${ }^{59}$, and given their definition ${ }^{60}$ cryptographic keys could be recognized as valid electronic signatures without stretching the concept. In the US commentators argued that 'Blockchain-based transactional records and the digital signatures associated with these records should also satisfy the statute of fraud's writing requirements' ${ }^{3}$, given that 'is no meaningful difference between a typewritten name [valid under US statutory signature requirements] and a digital signature affixed to a transaction triggering a smart contract using public private key cryptography, assuming the address can be uniquely tied to the signing party'. ${ }^{62}$ The one remaining challenge therefore remains in tying a public address to a party.

\section{COULD A STATUTORY “IN WRITING" BE MET IN THE CASE OF A SMART CONTRACT COMPOSED PARTLY OR WHOLLY OF A COMPUTER CODE?}

In English Law the default position is that there is a lack of writing requirements. Contracts are binding (assuming the foundational elements of a contract: offer and acceptance, consideration, intention to create legal relations, capacity are satisfied) without a requirement for written memorandum of the consensus

58 Golden Ocean Group Ltd v Salgocar Mining Industries PVT Ltd [2012] EWCA Civ 265, [38] (Tomlinson LJ).

59 Electronic Communications Act 2000, s 7(1).

60 Ibidem, s 7(2) defines "electronic signature" as: For the purposes of this section an electronic signature is so much of anything in electronic form as- (a) is incorporated into or otherwise logically associated with any electronic communication or electronic data; and (b) purports to be used by the individual creating it to sign.

61 Cardozo Blockchain Report, "'Smart Contracts'\& Legal Enforceability",p. 14, available at: https://cardozo.yu.edu/sites/default/files/Smart\%20Contracts\%20Report\%20\%232_0.pdf, 25.09.2019.

${ }^{62}$ Ibidem (emphasis added). 
ad idem. ${ }^{63}$ Accordingly, even if smart contracts are deemed to be unable to meet the writing requirement it does not invalidate the claim that Smart Legal Contracts can be recognized as legally binding agreements, because the most contracts will not have a statutory writing requirement (even if most contracts can be concluded in writing for convenience).

Further, a distinction has to be made between a 'wrapped' and 'pure' Smart Contract; a 'wrapped' contract (which is governed by an overarching natural language agreement, meaning code is only part of the arrangement) will self-evidently satisfy the "in writing" requirement as it is just a part of a written contract - a method of performing few of its provisions (assuming the overarching agreement is written). The following discussion will therefore center on contracts composed wholly of computer code.

There is however a class of contracts, which, to be valid, must be in writing: contracts for sale or other disposition of land ${ }^{64}$, bills of exchange, promissory notes, bills of sale ${ }^{65}$, and regulated consumer credit agreements ${ }^{66}$. The s 2 LP(MP)A requirement definitely is of upmost importance (as the most prominent "writing" requirement), yet as it deals with land the transaction will have to abide by several other formalities including a deed ${ }^{67}$ and registration ${ }^{68}$.

Consequently, a smart contract dealing with land (or more likely with a digitized token representing land), presuming it is for something other than a lease of less than 3 years $^{69}$, would not be the end of the story - there would be other steps where, at least currently, the law requires conventional forms of documentation which cannot be completed online or on a blockchain (such as registration). The point that is being made is that the most stringent "in writing requirement" under s 2 LP(MP)A would seldom pertain to smart contracts, as it deals with dispositions of interests in land, which under the current regime are largely inapt to be concluded by a smart contract.

Another interesting observation to make is that s $2 \mathrm{LP}(\mathrm{MP}) \mathrm{A} 1989$ 'applies only to executor contracts for the future sale or other disposition of an interest in

63 Halsbury's Laws of England: Contract (2012) Vol. 22, para 220.

64 Law of Property (Miscellaneous Provisions) 1989 (LP(MP)A), s 2(1).

65 Halsbury's Laws (n ), para 224.

66 Consumer Credit Act 1974, ss 8-9.

67 Law of Property Act 1925 (LPA 1925), s 52.

68 Land Registration Act 2002, s 27.

69 Short leases (leases under 3 years, taking effect in possession without a premium) do not have to be in writing and thus could be concluded orally or by a valid smart legal contract $-\mathrm{s} 54(2)$ LPA 1925. 
land, and does not apply to a contract which itself effects such a disposition. ${ }^{70}$ The CA held further that a lease is an example of the latter type $\mathrm{e}^{71}$ (hence untouched by s 2 LP(MP)A 1989). If this is true, in my own opinion it shouldn't as s 2(5) of the 1989 Act expressly says that it does not apply to short leases, so logically it should apply to other leases (but that is an irrelevant point here); a smart contract of the unilateral type (an offer uploaded to a blockchain, accepted by uploading the consideration, and performed and concluded at the point of acceptance) would automatically and immediately 'effect' a disposition of an interest in land - hence under the CA's view of s 2, there would, again, be no "in writing" requirement. The only possible caveat is that as on the blockchain the interest in land (freehold, leasehold, easement etc.) would be represented by a token, the smart contract would not be a disposition of the interest, but of a token, constituting in essence a promise to transfer the actual interest at a later date observing the formalities (such as registration). If that interpretation is instead adopted, then Smart Contracts would have to abide by the "in writing" requirements.

Coming back to the main point, there is statutory authority for the proposition that "writing" includes 'typing, printing, lithography, photography and other modes of representing or reproducing words in a visible form..$^{72}$ Prima facie, Solidity code, which is used for most of Ethereum Smart Contracts, would fall within 'mode of representing or reproducing words in a visible form' - it contains words although substitutes formal for natural syntax (words follow the internal logic of a computer-readable code, rather than a natural [i.e. human] language) - and thus be "writing".

An objection can be raised that computer code does not 'represent or reproduce words' - it is meant to convey a list of instructions to a computer, its ultimate objective is to be understood and performed by a machine, not to represent words. However, an IT specialist coding a smart contract has in his mind (or client instructions) a set of objectives in human language, that he then translates into computer code, or a Smart Contract. The Solidity Code (to continue with our example) can thus be said to 'represent' the natural language (words) in a way that render them readable to a machine. Hence, smart code could satisfy the statutory writing requirement.

70 Rollerteam Ltd $v$ Riley [2016] EWCA Civ 1291, [38] (Tomlinson LJ).

71 Ibidem.

72 Interpretation Act 1978, s 5, sch 1 (emphasis added). 
Furthermore, as a string of emails was held sufficient to satisfy the "in writing" requirement, ${ }^{73}$ a smart contract written in code (as a likewise electronic memorandum of an agreed bargain) should be recognized too. Tomlinson LJ reasoned that the point behind the "in writing requirement" was 'to ensure that a person is not held liable as guarantor on the basis of an oral utterance which is ill-considered, ambiguous or even completely fictitious. ${ }^{74}$ A smart contract, like an email, can also ensure that a party is not held bound by a mere oral utterance - perhaps even a fortiori - after all it requires much more effort to write precise computer code (evidencing a clearer intention to be bound) than just to reply 'I agree' in an email. Lastly, Tomlinson LJ urged that 'the statute must however, if possible, be construed in a manner which accommodates accepted contemporary business practice 75 - again that seems to indicate that once (if?) smart contracts become widely accepted throughout the commercial world, the courts, to accommodate business practice, will refuse to frustrate the obligation on a formality.

Another point can be raised: the legislation on consumer contracts requires that written terms in consumer contracts 'must always be drafted in plain, intelligible language. ${ }^{76}$ As it has been pointed out ' $\left.\mathrm{t}\right]$ he contractual parties are, in principle, free to choose any language for their contract which also includes "computer language"'77 - this leads to the inevitable difficulty that Smart Contract written in code may not be 'plain' or 'intelligible' to an ordinary consumer. It is argued that:

'Does this issue lead to an a priori prohibition of smart contracting in case of business to consumer transactions? The answer to this question is negative: it does not. However, this mandatory consumer protection requirement obliges businesses to provide consumers with plain, intelligible translations of the computer code which are understandable to them. Only if this condition has been fulfilled, consumer can be bound by a smart contract, and accordingly secures legality of smart contracting in case of business to consumer transactions. ${ }^{78}$

${ }^{73}$ Golden Ocean Group Ltd v Salgocar Mining Industries PVT Ltd [2012] EWCA Civ 265, [22]; dealing with Statute of Frauds 1677, s 4.

74 Ibidem, [21].

75 Ibidem, [22].

76 Council Directive 93/13/EEC of 5 April 1993 on unfair terms in consumer contracts [1993] OJ L 95/29, Art 5 (UCTD); Consumer Rights Act 2015, s 64(3).

77 Mateja Durovic, Andre Janssen, The Formation of Smart Contracts and Beyond: Shaking the Fundamentals of Contract Law?, 2018, p. 26.

78 Ibidem, p. 26. 
This interesting solution to the problem would mean that if there are any discrepancies between the computer code and natural language translation provided by the trader to the consumer, the natural translation would take precedence (as that was the document the consumer understood) and also as is required by the Directive 1993/13/EEC on unfair contract terms. ${ }^{79}$ This would undermine the viability of Smart Contracts in regulating B2C transactions - if for every smart contract a natural language translation is needed, and in effect that is the binding document (not the actual computer code), the Smart Contract is inevitably reduced to a mechanism of contractual performance, rather than being the substance of the contract. However, you seem to agree with the proposition that, in the absence of a natural language translation of the contract or wide prevalence of proficiency in $\mathrm{C}++$, JavaScript, Solidity etc., a Smart Contract would fail the "plain and intelligible" writing requirement under Consumer Protection Legislation.

Certain jurisdictions have introduced legislative provisions that deal exclusively with the application of the "in writing" requirement to electronically concluded contracts. For example in the Netherlands, an electronic contract satisfies the "in writing" requirement if: (a) the agreement is and remains accessible for the parties; (b) the authenticity of the agreement is sufficiently guaranteed; (c) the moment on which the agreement was formed, can be determined with sufficient certainty, and (d) the identity of the parties can be assessed with sufficient certainty. ${ }^{80}$ The first and the last requirements are said to pose the biggest challenge to the validity of Smart Contracts as "written" contracts. ${ }^{81}$ First a continuous line of computer code would not be "accessible", in the sense in which that term is understood in Dutch law (which means that the parties are able to access and save its contents in order to be able to inform themselves later about the agreement) ${ }^{82}$, as an ordinary consumer would not be able to "inform" themselves of the contents if written in formal language (code). Secondly, and as discussed above, parties to a smart contract posited on a blockchain could be difficult to assess with "sufficient" clarity.

Likewise in the US, contracts that require to be in writing under the Statute of Frauds must be signed and (a) reasonably identify the subject matter of the

79 Article 5 Directive 1993/13/EEC on unfair contract terms.

${ }^{80}$ Dutch Civil Code, $\$ 6: 227$ a. Available at: www.dutchcivillaw.com/civilcodebook066.htm, 25.09.2019.
81 J. Madir, p. 12.
82 Ibidem, p. 12. 
contract (b) be sufficient to indicate that a contract with respect thereto has been made between the parties or offered by the signer to the other party, and (c) state with reasonable certainty the essential terms of the unperformed promises in the contract. ${ }^{83}$ That requirement includes a requirement to reasonably identify the contracting parties. ${ }^{84}$ This again poses a threat to the ability of Smart Contracts to satisfy the "in writing requirement" in the States. However, it has been argued that in assessing the validity the American Courts have adopted a commonsense approach looking as to whether a contract was written down incorporating the essential terms and subject matter and whether it was signed with intention to "authenticate". 85

Crucially, under the English law, there isno statutory requirement as to what is required of electronic contracts to be considered that they are in writing. Under English law a contract must be in writing, signed by both parties and incorporating all the terms which the parties have expressly agreed ${ }^{86} \mathrm{~A}$ smart contract is definitely more than capable of fulfilling those requirements, subject to the discussion of "signature" above. Perhaps however, in the avoidance of doubt a legislative document should spell out the requirements that a smart contract would have to abide by to satisfy the requirement.

\section{CONCLUSIONS}

This paper examined the enforceability of smart contracts under the English contract law. What may be concluded is that, under the current English law, commercial transactions wrapped in the form of smart contracts should be enforceable as contracts before the courts if they fulfil all of the existing requirements necessary for enforcement of any kind of contract. It seems that no changes of English law need to be made to secure enforceability of smart contracts. Smart contracts are to be understood just as emanation of freedom to contracts where smart contract is agreed to be used as an instrument for execution of a promise established under a contract. This would be the case, for example, with using smart contracts to secure that a certain amount of money as a price established under the contract will be transferred to the seller once the good have been delivered to the buyer.

\footnotetext{
${ }^{83}$ US Restatement (Second) Contracts, $\$ 131$.

${ }^{84}$ Cardozo Project, p. 10.

85 Ibidem, p. 11.

86 LP(MP)A 1989, s 2(1).
} 
Moreover, in case of types of contracts for whose enforceability is required to be in writing, smart contracts composed wholly of computer code can satisfy statutory "in writing" requirement.This is because smart contracts are a method of expression that represent words in a durable medium, preventing parties from being bound by an inadvertent utterance.

\title{
Dr MATEJA DUROVIC
}

vanredni profesor, King's College London

Dr FRANCISZEK LECH

istraživač, King's College London

\section{IZVRŠIVOST “PAMETNIH” UGOVORA}

\author{
Rezime
}

Razvoj novih tehnologija je izvršio značajan uticaj i na pravo. "Pametni” ugovori (smart contracts) su jedan od oblika novih tehnologija koji dovodi u pitanje primenu tradicionalnog ugovornog prava na privredne transakcije koje se odvijaju putem "pametnih" ugovora. Tako, izvršivost transakcija zaključenih putem ove vrste ugovora postaje jedno od glavnih pravnih pitanja. Takođe, postavlja se pitanje da li je potrebno izmeniti postojeće englesko ugovorno pravo kako bi se osiguralo izvršenje "pametnih" ugovora. Autori će u radu potražiti odgovor na postavljena pitanja u cilju boljeg razumevanja odnosa tradicionalnog ugovornog prava, s jedne strane, i "pametnih" ugovora, s druge strane.

Ključne reči: pametni ugovori (smart contracts), ugovorno pravo, poremećaj, nove tehnologije, AI, izvršivost

\section{Bibliography}

Allen Jason G., "Wrapped and Stacked: "Smart Contracts" and the Interaction of Natural and Formal Language", 14(4) ERCL, 2018.

Ashurst LLP, “Smart Contracts - Can Code Ever Be Law?", available at: https://www.ashurst.com/en/news-and-insights/legal-updates/smart-contracts---can-code-ever-belaw/.

Cannarsa Michel, "Interpretation of Contracts and Smart Contracts: Smart Interpretation or Interpretation of Smart Contracts?", European Review of Private Law, Vol. 26, No. 6, 2018.

Cardozo Blockchain Report, "Smart Contracts'\& Legal Enforceability", p. 14, available at: https://cardozo.yu.edu/sites/default/files/Smart\%20Contracts\%20Report $\% 20$ \%232_0.pdf. 
Cenkus Law, 'Smart Legal Contracts: Explanation and Enforceability', available at: https:// cenkuslaw.com/smart-contracts-explained-legally-binding/.

Clifford Chance, "Smart Contracts: Legal Agreements for the Digital Age" (No 2017), available at: https://talkingtech.cliffordchance.com/content/micro-cctech/en/emerging-technologies/smart-contracts/smart-contracts/_jcr_content/text/parsysthumb/ download/file.res/Smart\%20contracts.pdf.

Cuccuru Pierluigi, "Beyond Bitcoin: An Early Overview On Smart Contracts”, International Journal of Law and Information Technology, Vol. 25, No. 3, 2017.

Durovic Mateja, Janssen Andre, “The Formation of Smart Contracts and Beyond: Shaking the Fundamentals of Contract Law?”, 2018.

Gonzales Rivas Alvaro, Tsyganova Mariya, Mik Eliza, 'Smart Contracts and Their Identity Crisis',p. 8, available at: https://papers.ssrn.com/sol3/papers.cfm?abstract_ $\mathrm{id}=3319612$.

Governatori Guido, Riveret Régis, Xu Xiwei, Idelberger Florian, Sartor Giovanni, Milosevic Zoran, "On Legal Contracts, Imperative and Declarative Smart Contracts and Blockchain Systems”, Artificial Intelligence Law, Vol. 26, 2018.

Grimmelmann James, "All Smart Contracts Are Ambiguous", Penn Journal of Law and Innovation (Forthcoming).

Lipshaw Jeffrey, “Persistence of 'Dumb' Contracts”, Stanford Journal of Blockchain Law \& Policy, Vol. 2, 2019.

Madir Jelena, "Smart Contracts: (How) Do They Fit Under Existing Legal Framework", p. 3, available on SSRN at: https://poseidon01.ssrn.com/delivery. php? ID $=44104 \& E X T=$ pdf.

Pardolesi Roberto, Davola Antonio, "What is Wrong in the Debate About Smart Contracts”, Luiss Guido Carli University Working Paper, 2019.

Tse Gary, "Smart Contracts: A Boon or Bane For the Legal Profession”, available at: https:// www.taylorvinters.com/article/smart-contracts-a-boon-or-bane-for-the-legal-profession.

US Chamber of Digital Commerce, “Smart Contracts: Is the Law Ready?”, p. 35, available at: https://digitalchamber.org/smart-contracts-whitepaper/.

Article history

Received: 24.09.2019.

Accepted: 22.10.2019. 